\title{
The Effect of Philosophy Understanding on Corona Virus Diseases (COVID-19) Prevention Awareness of Physics Education Students
}

\author{
Ahmad Syukri* \\ Islamic Philosophy Department, Postgraduate \\ Islamic State University of Sulthan Thaha Saifuddin \\ Jambi, Indonesia \\ *ahmadsyukriss@uinjambi.ac.id
}

\author{
Sukarno \\ Physic Education Department \\ Islamic State University of Sulthan Thaha Saifuddin \\ Jambi, Indonesia \\ sukarno@uinjambi.ac.id
}

\begin{abstract}
This research aims to answer the question of how the influence of understanding philosophy on awareness of prevention of Corona Virus Diseases (COVID-19)? The approach used in this research is quantitative with the data collection method is a survey. The respondents used in this study were 80 students at UIN STS Jambi, where they had taken philosophy courses. The data collection instrument consisted of 30 questions to identify and score the three variables. Data analysis was performed using a two-variable multiple linear regression test with the help of SPSS 25 software. Based on the description of the test results above, it can be seen that the correlation coefficient value between variables is 0.160 . This shows that the ability to understand philosophy does not affect self-awareness in preventing COVID-19. The influence is only around 16\%. The remaining $84 \%$ is influenced by other factors. Therefore, it can be said that understanding the concept of philosophy has a less strong influence on individual self-awareness in following government recommendations for the prevention of COVID-19. In other words, the research results show that understanding philosophy does not directly affect student awareness in the process of preventing COVID-19. Thus it can be understood that the understanding of philosophy has an indirect impact on the process. Philosophy plays a role since the design of the educational process and the educational process that has a direct impact on changing one's behavior in this context is awareness in preventing COVID-19.
\end{abstract}

Keywords-understanding philosophy, awareness of COVID-19 prevention

\section{INTRODUCTION}

Philosophy is the study of all phenomena of life, and critical human thought and is described in fundamental concepts "Philosophy,". Philosophy in general is thinking thoroughly, deeply, radically, and rationally, about something [1]. Philosophy does not involve conducting experiments, and experiments, but by defining a problem precisely, finding a solution to it, providing arguments, and the right reasons for a particular solution. Philosophy studies and thinks about the essence of everything as a whole, systematically, integrated, universal, and radical, the results of which become the guidelines and direction of the development of the sciences concerned [2].

Humans are physical and spiritual beings, also, they become superior beings among other creatures created by Allah SWT. Philosophical thinking is speculative, which means reflecting, thinking about something deeply, without the need for direct contact with the object being thought about [2]. Thus it can be understood that every human being has two dimensions that are closely related to each other, namely body and spirit, which then both will influence the human in thinking, behaving, and acting. In short, "philosophy" is a science that humans achieve with their minds. Philosophers/studying various problems of the universe, sky, earth, humans, animals, plants, minerals, and so on [3].

Philosophy has a very important role in ensuring the welfare of humanity itself. For example; To conduct scientific research properly, students at the academy/university level must know the scientific method, ethical values, and pragmatic values studied from the philosophy of science [4]. This is also in line with the opinion Malian [5] that the philosophy of science is a branch of philosophy that is very useful for explaining what the goals of science are for humans. Philosophy of science can be the basis for a reflection or thought strictly, in-depth about the value consideration behind the phenomena of law as can be observed by the human senses regarding human actions and social habits. The explanation above is also supported by Wili [6] that the philosophy of science is very important because it will encourage people to be more creative and innovative. The philosophy of science provides a spirit for the development and advancement of science and at the same time, the moral values contained in each science at the ontological, epistemological, and axiological levels.

\section{A. Islam and Philosophy}

In the Islamic intellectual tradition, it is found that there is a term commonly used for philosophy or "Sophia", namely 
"hikmah". This term was used by an early generation of Muslim thinkers as the equivalent of the word "Sophia". The words of "wisdom" is deliberately chosen so that it is more easily accepted by Muslims so that it is impressed that philosophy is not contrary to the teachings of Islam but instead originated and empties into the Qur'an [3]. Thus Islam as a perfect religion is precisely in line with philosophical studies. However, not all philosophical studies are by Islamic teachings, this is because philosophy is the result of human thought, while Islam comes from God.

Islamic philosophy is to think as a whole, radically and rationally as a continuous process of seeking the truth continuously and in the end, it is understood the meaning of everything, including the meaning of human life and the whole series related to it. Strictly speaking, Islamic philosophy at the ontological level is the essence of humanity and humanity, and at the epistemological level comes from the Qur'an and the Sunnah of His Prophet, in addition to the potential senses, reason, heart (intuition), and at the level of aksilogis is of value for the welfare human life physically and mentally [6].

Divine philosophy teaches humans to know God through mere reasoning, which is then found by revelation (holy book) [7]. Islamic philosophy is closely related to the search for the truth of humanity which comes from the Qur'an and Sunnah, which do not leave senses, reason, and intuition [1]. Islamic philosophy (Law) covers the whole scope of fiqh, ushul fiqih, legal secrets, wisdom, and maqashid as shari'ah [8].

Islamic philosophy carries an implicit agenda and mission, how to align the teachings of revelation with the demands of reason, even though in essence this kind of dichotomy is not a central issue in Islamic philosophical discourse [3]. The use of philosophical approaches as referred to above, so that moral and religious values can be understood to their most essential or fundamental nature. Because philosophically it is only such an approach that allows the essence, moral and religious functions to be known and understood as they should [1].

In general, it can be said that ethics is a philosophy about human actions as humans. An action that has an ethical value if done by humans and in a humane framework [9]. This is in line with the opinion Jenilan [2] that, in contrast to other creatures whose relationship with nature is natural and in the form of absolute submission, human relations with nature contain elements of endeavor, or efforts to live humanely. Besides, one of the results of the study concluded that the philosophy of science plays a very important role in the development of legal science. In other words, the philosophy of science as a philosophy that has a high position in the layer of legal science is the basis and direction for the development of legal science [10].

\section{B. Awareness of COVID-19 Prevention as a Form of Human Existence}

Self-awareness is a manifestation of a person's identity, which can be referred to as a personal identity when the person concerned is reflected in his appearance, sense of creativity and intention, value system, perspective, and behavior [11]. Selfawareness is a tool for controlling life. The most important thing in this context is that a believer can know that he is a very valuable creation of God and does not see himself as another animal that only has a basic need to be satisfied and fought for. Self-awareness is knowing what you are feeling at a moment using it to guide one's own decision making. In addition, selfawareness also means setting realistic benchmarks for selfefficacy and strong self-confidence [12].

In the Oxford English Dictionary (OED), there are six meanings of consciousness which are complemented by references according to OED, namely: (a) shared knowledge (b) internal knowledge or belief (c) a mental state of being aware of something (awareness), (d) recognizing actions or feelings themselves (direct awareness), (e) personal unity that is the totality of impressions, thoughts, feelings that form conscious feelings and (f) the state of wake/awake normally. Each meaning of the word provides a different pressure point and meaning. However, based on the explanation of the meaning of the word he above, in general, it can be said that consciousness is one's internal knowledge or belief to realize something that is manifested in the form of one's actions or feelings.

Islam as a teaching not only regulates the relationship between humans and God but also regulates the relationship between humans and fellow humans, which includes various aspects of life, including health problems. In Islamic doctrine, maintaining health is better than overcoming disease [13]. In Islam, warnings and caution against leprosy (infectious diseases) were also widely recognized during the lifetime of the Prophet Muhammad advised people to avoid leprosy as they run away from lions.

In Islam, all actions that present a potential danger, in fiqh, are classified as haram, even though they are based on correct aqidah. Likewise, the Prophet Muhammad, although he taught that no disease can be transmitted by itself without control from Allah, at the same time he also instructed the sick not to mix with the healthy so that transmission would not occur [14]. This is also told in the history of Islam, namely Umar bin Khatab. He did not give up and continued his plan to visit the affected area while calling on his other friends to pray for what might happen to them. On the other hand, Caliph Umar took a firm decision to cancel the planned visit, which made many friends protest against Umar's attitude [15].

Currently, a very dangerous infectious disease is coronavirus-19. The coronavirus disease (COVID-19) outbreak is designated as a Public Health Emergency Concerning the World (PHEIC) and the virus has now spread to various countries and territories [16]. The World Health Organization or WHO has declared that the Corona Covid-19 virus is a pandemic and the Indonesian government has also stated that the Coronavirus problem has become a non-natural national disaster [17].

The spread of the virus, which the antidote has not yet been found, is out of control. More than 200 countries in the world 
have reported cases of exposure to coronavirus [18]. This virus can be transmitted from human to human and has spread widely in China and more than 190 other countries and territories [19]. The coronavirus is a pandemic that is easily spread contagiously. Therefore, many leaders urge their citizens to carry out social distancing and isolation to prevent the transmission of this disease virus [20].

Existentialism is rooted in efforts to rise from all hegemony to find the existence and essence of oneself. To find the existence of the self, humans must be aware because there are no other creatures that exist other than humans [21]. Existence essentially points to human consciousness, because man is dealing with the world in which he is at the same time taking responsibility for himself and the future of his world. Humans are responsible for themselves. In shaping himself, humans should choose various alternatives and their choices must be accounted for by themselves, cannot blame others, cannot depend on God. Therefore, humans have absolute freedom [22].

Referring to the description above, this study aims to see to what extent the influence of understanding the students of physics education at the Tarbiyah and Teacher Training Faculty at the Islamic State University of Sulthan Thaha Saifuddin Jambi on awareness of the prevention of Covid-19 disease. Thus the question that will be answered in this study is how the influence of understanding the philosophy of students at the Islamic State University of Sulthan Thaha Saifuddin Jambi on awareness of the prevention of Covid-19 disease?

\section{METHODS}

This study uses a quantitative approach with a survey method. The survey data were obtained through telephone networks and WhatsApp (WA) so that researchers and respondents did not meet each other. The sample is students majoring in Physics Education at the Teacher Training and Education Faculty at the Islamic State University of Sulthan Thaha Saifuddin, Jambi who are spread across several semester levels. In the study, the selection of respondents was carried out randomly with the limitations that they had attended philosophy lectures. These students are generally in the third semester and above. The total number of respondents used in this study was 80 people. The instrument used in the study was a 30-point question designed in such a way that it could be answered with "yes" or "no". All questions were focused on seeing the understanding of the respondent's philosophical concepts and self-awareness regarding the prevention of COVID-19. Every "yes" answer will get a score of 1 and every "no" answer will get a score of 0 . Therefore, each respondent will get a maximum score of 30 and a minimum score of 0 .

As mentioned above, this study aims to examine the influence of the variable understanding of philosophy $(\mathrm{X})$ on self-awareness $(\mathrm{Y})$ in actively participating in the prevention of COVID-19, either independently or jointly with certain community groups. Thus the data analysis was carried out using a two-variable double linear regression test followed by a
T-test to see whether the two variables (X) had a partial or joint effect on variable $\mathrm{Y}$. As for seeing whether the two variables simultaneously affected the self-awareness bar. (Y) then the F. test is performed

\section{RESULTS AND DISCUSSION}

Based on data obtained from respondents using instruments that have been developed, then data analysis is carried out. The first data analysis was carried out by classifying the level of ability of each respondent based on the scale of the scores they obtained, namely in the "high", "medium" and "low" categories. Based on this classification, data is obtained as in Table 1 below.

TABLE I. UNDERSTANDING THE CONCEPT OF PHILOSOPHY AND SELFAWARENESS IN PREVENTION OF COVID-19

\begin{tabular}{|c|c|c|c|c|c|}
\hline Aspect & Score & $\begin{array}{c}\begin{array}{c}\text { Number } \\
\text { of } \\
\text { Students }\end{array} \\
\text { Student }\end{array}$ & $\begin{array}{l}\text { Average } \\
\text { of Score }\end{array}$ & $\begin{array}{c}\text { Percentage } \\
(\%)\end{array}$ & Category \\
\hline \multirow{4}{*}{$\begin{array}{l}\text { Understanding } \\
\text { of Philosophy }\end{array}$} & $21-30$ & 6 & \multirow{3}{*}{14,5} & 7,5 & High \\
\hline & $11-20$ & 38 & & 47,5 & Moderate \\
\hline & $0-10$ & 36 & & 45 & Low \\
\hline & Total & 80 & & 100 & \\
\hline \multirow{4}{*}{$\begin{array}{l}\text { Self- } \\
\text { Awareness on } \\
\text { COVID-19 } \\
\text { prevention }\end{array}$} & $21-30$ & 26 & \multirow{3}{*}{15,0} & 32,5 & High \\
\hline & $11-20$ & 23 & & 28,75 & Moderate \\
\hline & $0-10$ & 31 & & 38,75 & Low \\
\hline & Total & 80 & & 100 & \\
\hline
\end{tabular}

Based on Table 1 above, it can be seen that the average score of philosophical understanding obtained by respondents is 14.5. This score indicates that in general, the ability to understand the philosophical concepts of the respondents is in the medium category. This fact is also reinforced by the percentage level of the ability to understand philosophy which is dominated by the moderate category group, namely $47.5 \%$, followed by low ability (45\%), and the high ability group as much as $7.5 \%$.

Besides, based on Table 1, it can also be seen that in general self-awareness in following government recommendations in preventing COVID-19 is in the medium category. This is indicated by the average score of self-talk and prevention of COVID-19 which is 15.0 (moderate). However, if it is seen in Table 1 above, it can be seen that the low category group occupies the highest percentage, namely $38.75 \%$, and is followed by the high category as much as $32.5 \%$. The group with a moderate level of awareness was $28.75 \%$.

Based on the scores obtained by the respondents during the survey, which involved 80 students majoring in physics education at the Islamic State University of Sulthan Thaha Saifuddin, Jambi and then the scores were analyzed to determine the correlation between variables. As for the results of data analysis with the help of SPSS 25 software, the output model summary is shown in table 2 below. 
TABLE II. MODEL SUMMARY, CORRELATIONS BETWEEN VARIABLES

\begin{tabular}{|l|l|l|l|l|}
\hline & & & Philosophy & Self-Awareness \\
\hline $\begin{array}{l}\text { Spearman' } \\
\text { S rho }\end{array}$ & Philosophy & $\begin{array}{l}\text { Correlation } \\
\text { Coefficient }\end{array}$ & 1.000 & .160 \\
\cline { 3 - 5 } & & Sig. (2-tailed) &. & .157 \\
\cline { 3 - 5 } & $\mathrm{N}$ & 80 & 80 \\
\cline { 3 - 5 } & $\begin{array}{c}\text { Self- } \\
\text { Awareness }\end{array}$ & $\begin{array}{l}\text { Correlation } \\
\text { Coefficient }\end{array}$ & .160 & 1.000 \\
\cline { 3 - 5 } & Sig. (2-tailed) & .157 &. \\
\cline { 3 - 5 } & $\mathrm{N}$ & 80 & 80 \\
\hline
\end{tabular}

Based on the summary test model above, it can be seen that the correlation coefficient value between variables is 0.160 . This shows that the ability to understand philosophy does not affect self-awareness in preventing COVID-19. The influence is only around $16 \%$. The remaining $84 \%$ is influenced by other factors. Therefore, it can be said that understanding the concept of philosophy has a less strong influence on individual selfawareness in following government recommendations for the prevention of COVID-19.

As mentioned above, that $84 \%$ of physics students are interested in following the government's queues for COVID-19 prevention, which is influenced by other factors beyond the philosophy they have previously obtained. It is suspected that awareness of COVID-19 prevention is more influenced by information and digital literacy skills. This is because all information related to the spread of COVID-19 was obtained by the public and the students came from mass media and social media. Because of this factor, this awareness emerged. This is also in line with the opinion Aini [23] that literacy culture affects the development of civic intelligence. Of course, in this case, is awareness and compliance with the rules set by the government.

Also, another factor that is strongly thought to underlie the awareness of physics students in preventing the spread of COVID-19 is scientific literacy. This is understandable considering that COVID-19 is closely related to science, both in the structure of the disease, the process of spread, and prevention. Therefore, scientific literacy is believed to have played a role in developing public awareness including students in preventing disease. This is in line with the opinion Reiss [24] that science education contributes and has the opportunity to introduce students to the COVID-19 disease. Also, Nofiana and Julianto [25] stated that low scientific literacy causes students to be less responsive to developments and problems around the environment, especially those related to natural phenomena, local regional excellence, and problems in the surrounding environment. Therefore, it can be understood that students' scientific literacy contributes to awareness of preventing COVID-19.

Another factor that is also thought to have contributed to preventing the spread of COVID-19 is health literacy. This is in line with the opinion Paakkari and Okan [26] and Abel and
McQueen [27] that health literacy plays a role in one's knowledge related to diseases including COVID-19. Besides Lazcano-Ponce and Alpuche-Aranda [28] also state that health literacy is a process to acquire knowledge, motivation, and individual competence to understand and access information, express opinions, and make decisions regarding health promotion and maintenance. This applies in different contexts, environments, and throughout life. This conceptual perspective is very much needed in dealing with the emergency of the Covid-19 virus.

Referring to the description above, it can be understood that the research results show that understanding philosophy does not directly affect student awareness in the process of preventing COVID-19. Thus it can be understood that the understanding of philosophy has an indirect impact on the process. This is as stated by Hafid [29] that the philosophy with all these schools is considered to have contributed to putting the concept of education by taking into account the trend angle in determining the existence of intellect and potential possessed by humans. Thus the role of philosophy has started since the design of the education process and then the educational process which has a direct impact on changing one's behavior in this context is awareness in preventing COVID-19.

The findings above are also in line with philosophy itself, namely the positivism in which Aguste Comte is a figure of this school. The opinion of this school is that the senses are very important in obtaining knowledge, but must be sharpened with tools and strengthened by experiment. When viewed from its ethical value towards science, it can be stated that if the positivism paradigm is, the object is empirical, such as knowledge that shows science and can be measured logically and empirical evidence [30]. Therefore, it can be understood that philosophy encourages a person to acquire knowledge, while the impact of knowledge is behavior. This is the reason why understanding one's philosophy does not directly affect COVID-19 prevention behavior.

Referring to the educational theory, learning is interpreted as a process of changing behavior as a result of individual interactions with their environment. Changes in the behavior of learning outcomes are continuous, functional, positive, active, and directed, the process of behavior change can occur in various conditions [31]. Thus, self-awareness behavior in preventing COVID-19 is more the result of an educational process that is compiled and developed based on philosophy (education).

Based on the description (research results), to produce students with good character or behavior, planning, implementation, and evaluation in education should consider philosophy. This is because philosophy has a role far upstream rather than downstream. Besides, philosophy courses also need to be introduced to every student from an early age, so that from the beginning each person has an awareness of himself and his environment including in terms of maintaining health. 


\section{CONCLUSION}

Based on the description of the results of the test research above, it can be seen that the correlation coefficient value between the variables is 0.160 . This shows that the ability to understand philosophy does not affect self-awareness in preventing COVID-19. The influence is only around $16 \%$. The remaining $84 \%$ is influenced by other factors. Therefore, it can be said that understanding the concept of philosophy has a less strong influence on individual self-awareness in following government recommendations for the prevention of COVID19. In other words, the research results show that understanding philosophy does not directly affect student awareness in the process of preventing COVID-19. Thus it can be understood that the understanding of philosophy has an indirect impact on the process. Philosophy plays a role since the design of the educational process and the educational process that has a direct impact on changing one's behavior in this context is awareness in preventing COVID-19.

\section{ACKNOWLEDGMENT}

This research was carried out by involving various parties, both those involved directly or indirectly. Therefore, the authors would like to express their deepest gratitude and appreciation to all parties involved in the research to the writing of the report and publication of the research results. Acknowledgments and high appreciation from the author to the Chancellor of the State Islamic University of Sulthan Thaha Saifuddin Jambi and the Head of the Tarbiyah and Teaching Faculty of the Islamic State University of Sulthan Thaha Saifuddin and all participants who actively participated in this research. Hopefully, research can provide positive benefits and contributions to the development of science in the future.

\section{REFERENCES}

[1] H. Yusuf, "Urgensi Filsafat Dalam Kehidupan Masyarakat Kontemporer: Tinjauan Filsafat Islam terhadap Fungsi Moral dan Agama," Jurnal Theologia, vol. 27, pp. 51-72., 2016.

[2] J. Jenilan, "Filsafat Pendidikan," EL-AFKAR: Jurnal Pemikiran Keislaman Dan Tafsir Hadis, vol. 7(1), pp. 69-74, 2018.

[3] S. Arif, "Filsafat Islam antara Tradisi dan Kontroversi," TSAQAFAH, vol. 10, pp. 1-22, 2014.

[4] D.T. Winata, "Manfaat kajian filasafat, nilai etika, dan pragmatis ilmu pengetahuan untuk melakukan penelitian ilmiah," Jurnal Ilmiah WIDYA, vol. 2, pp. 32-40, 2014

[5] S. Malian, "Perkembangan Filsafat Ilmu Serta Kaitannya Dengan Teori Hukum," UNISIA, vol. 33, 2012.

[6] C. Wili, "Tujuan dan Manfaat Filsafat Ilmu," 2012. [Online] Retrieved from:

https://www academia.edu/25475072/Jurnal_Ilmiah_Tujuan dan Manfa at_Filsafat_Ilmu_TUJUAN_DAN_MANFAAT_FILSAFAT_ILMU

[7] M. Noor, "Filsafat Ketuhanan,” J. Humaniora Teknologi, vol. 3, 2017.

[8] M. Fateh, Rekonstruksi pemikiran filsafat hukum Islam Hasbi AshShiddieqy (kajian metodologis). J. Hukum Islam, vol. 11, 67-94, 2013.

[9] A.W. Dewantara, Filsafat Moral. Sleman: Kanisius, 2017.
[10] K. Anwar, "Peranan Filsafat Ilmu Dalam Penemnangan Ilmu Hukum," Fiat Justisia, vol. 7, 2013

[11] M. Malikah, "Kesadaran Diri Proses Pembentukan Karakter Isla," AlUlum, vol. 13, pp. 129-150, 2013.

[12] H. Sastrawinata, "Pengaruh Kesadaran Diri, Pengaturan Diri, Motivasi, Empati, Dan Keterampilan Sosial Terhadap Kinerja Auditor Pada Kap Di Kota Palembang," Sosialita, vol 1, 2011.

[13] N. Nurhayati, "Kesehatan dan Perobatan dalam Tradisi Islam: Kajian Kitab Shahih Al-Bukhârî”. AHKAM, vol. 16, pp. 223-228, 2016.

[14] A.W. Ahmad, "Melihat Corona dari Perspektif Aqidah dan Fiqih," 2020. [Online] Retrieved from: https://islam.nu.or.id/post/read/117874/ melihat-corona-dari-perspektif-aqidah-dan-fiqih

[15] A.C. Effendy, "Teladan Sahabat Umar dan Amr bin Al-Ash saat Wabah Tho'un Amwas," 2020. [Online] Retrieved from: https://www.hidayatullah.com/berita/berita-darianda/read/2020/03/17/180002/teladan-sahabat-umar-dan-amr-bin-al-ashsaat-wabah-thoun-amwas.htm

[16] WHO, Pesan dan Kegiatan Utama Pencegahan dan Pengendalian COVID-19 di Sekolah. UNICEF, 2020.

[17] Z. Zahrotunnimah, "Langkah Taktis Pemerintah Daerah Dalam Pencegahan Penyebaran Virus Corona Covid-19 di Indonesia," SALAM: Jurnal Sosial Dan Budaya Syar-I, vol. 7, pp. 247-260, 2020

[18] N. Yunita, "Penyebab, Asal Mula, dan Pencegahan Virus Corona di Indonesia," $2020 . \quad$ [Online] Retrieved from: https://news.detik.com/berita/d-4956764/penyebab-asal-mula-danpencegahan-virus-corona-di-indonesia

[19] A. Susilo, C.M. Rumende, C.W. Pitoyo, W.D. Santoso, M. Yulianti, H Herikurniawan, and E. Yunihastuti, "Coronavirus Disease 2019: Tinjauan Literatur Terkini,” Jurnal Penyakit Dalam Indonesia, vol. 7, pp. 45-67, 2020.

[20] N. Mona, "Konsep Isolasi Dalam Jaringan Sosial Untuk Meminimalisas Efek Contagious (kasus Penyebaran Virus Corona Di Indonesia)," Jurnal Sosial Humaniora Terapan, vol. 2, 2020.

[21] F.M. Yunus, "Kebebasan Dalam Filsafat Eksistensialisme Jean Pau Sartre,” Jurnal Al-Ulum, vol. 11, pp. 267-282, 2011.

[22] Y. Hambali and S. Asiah, "Eksistensi Manusia dalam Filsafat Pendidikan: Studi Komparatif Filsafat Barat dan Filsafat Islam," Turats, vol. 7, pp. 42-56, 2011.

[23] D.N. Aini, "Pengaruh Budaya Literasi Dalam Mengembangkan Kecerdasan Kewarganegaraan," Biormatika Jurnal Ilmiah FKIP Universitas Subang, vol. 4, 2018.

[24] M.J. Reiss, "Science Education in the Light of COVID-19: The Contribution of History, Philosophy, and Sociology of Science," Science and Education, vol. 29, pp. 1079-1092, 2020.

[25] M. Nofiana, and T. Julianto, "Upaya Peningkatan Literasi Sains Siswa Melalui Pembelajaran Berbasis Keunggulan Lokal," Biosfer: Jurnal Tadris Biologi, vol. 9, pp. 24-35, 2018.

[26] T. Abel and D. McQueen, "Critical health literacy and the COVID-19 crisis. Health Promotion International," Health promotion international, vol. 35, pp. 1612-1613, 2020.

[27] L. Paakkari and O. Okan, "COVID-19: health literacy is an underestimated problem," Lancet Public Health, vol. 5, 2020.

[28] E. Lazcano-Ponce and C. Alpuche-Aranda, "Public health literacy in the face of the Covid-19 pandemic emergency," Salud Publica de Mexico, vol. 62, pp. 331-340, 2020.

[29] A.H. Saidah, "Pemikiran Essensialisme, Eksistensialisme, Perenialisme, dan Pragmatisme dalam Perspektif Pendidikan Islam,” Jurnal Al-Asas, vol. 5, pp. 16-28, 2015.

[30] I. Nugroho, "Positivisme Auguste Comte: Analisa Epistemologis Dan Nilai Etisnya Terhadap Sains,” Cakrawala: Jurnal Studi Islam, vol. 11, pp. 167-177, 2016.

[31] M.S. Hanafy, "Konsep belajar dan pembelajaran," Lentera Pendidikan Jurnal Ilmu Tarbiyah dan Keguruan, vol. 17,pp. 66-79, 2014 